He was also a lover of music and at one time was a member of the Alexandra Palace Choir and in latter years his local church choir.

Archie Holness leaves two sons and two daughters to whom he had been a wonderful father. His wife predeceased him a year or two ago after many years of illness during which he gave her devoted care. Naturally at his advanced age few of his intimate friends remain to mourn his passing but there are still many of his younger colleagues, like the writer, who will always remember with affection and gratitude his friendship and the great assistance he gave to their training.

B. G. TURNER

\title{
STANLEY FRANK ISAAC
}

STANLEY ISAAC was born on 1 February 1906 and died on 12 April 1972 after a short illness. On leaving school in 1924, he joined the Atlas Assurance Company Limited and remained with that Company and the Royal Exchange Group, into which it was merged, throughout his entire business career. He was appointed Assistant Actuary of the Atlas in 1937, Deputy Actuary in 1944 and Actuary and Life Manager in 1946. In 1963, he became an Assistant General Manager of the Royal Exchange Group, which appointment he held until his retirement in 1967.

Isaac qualified as a Fellow of the Institute in 1928 at the early age of twenty-two and served the Institute in many capacities-Examiner 1936-38, Honorary Secretary 1951-53, Vice-President 1955-58 and Member of Council for seventeen years between 1946 and 1965. He was also editor of the Journal of the Students' Society in 1933-35 and Chairman of that Society in 194850. In 1945 he submitted, jointly with R. W. A. Fowler, a paper to the Institute on 'The Financial Investigation of Charitable Funds' (J.I.A. 1946, 72, 415). He was active in the affairs of the Life Offices' Association for many years and was its Chairman in 1961-62.

One of his great interests was the Insurance Charities and he was a member of the General Committee for over twenty years. In addition he was Honorary Actuary from 1945 until 1959 and President in 1960. Thereafter he became a Vice-President and in 1967, when in retirement, he was Chairman of a study group which examined in detail the affairs of the Charities and drew up proposals for reorganization.

In addition to activities connected with the profession and the insurance industry, Isaac devoted much time and energy to the affairs of the Congregational Church and of the British Home and Hospital for Incurables at Streatham. He was a Deacon and Treasurer of the Congregational Church at Caterham and served on the Finance Committee of the Congregational Church of England and Wales. In 1960 he was elected to the Board of the British Home, later becoming Chairman of the Finance Committee and Vice-Chairman of the Board and, in 1971, Chairman of the Buard.

Notwithstanding the demands of all these activities, he always found time to spend with his family, to whom he was devoted, and he took great pride in his home and, particularly, in his garden.

A man of strong convictions and principles with an immense capacity for hard work, application to detail and regard for strict accuracy and precision of expression, he successfully combined these qualities with kindness and a real understanding of the problems of his fellow men. By his example he was an inspiration to all with whom he came into contact and he will be remembered particularly for his selfless devotion to the interests of others in his business, professional and private life, epitomized in these words spoken at the service held in his memory, 'He was a good man, full of the Holy Spirit and of faith'.

O. V. HACKETT 